\title{
Albendazole Sulphoxide Administered Prior to Mating and its Relation with Fertilization and Mouse Embryo Development
}

\author{
Albendazol Sulfóxido Administrado Previo al Apareamiento y su Relación \\ con la Fertilización y el Desarrollo Embrionario de Ratón
}

*,**Teruel, M.; **Catalano, R. \& *Salomón, L.

TERUEL, M.; CATALANO, R. \& SALOMÓN, L. Albendazole sulphoxide administered prior to mating and its relation with fertilization and mouse embryo development. Int. J. Morphol., 29(3):816-820, 2011.

SUMMARY: The aim of this work was to evaluate the effect of albendazole sulphoxide (ABZSO) administered to Balb C mice prior to mating on fertilization rate and preimplantational embryo development. Twenty four female mice 5-8 weeks of age were superovulated by intraperitoneal injection of 7.5 UI of equine chorionic gonadotropin (eCG, Novormon®, Laboratorios Syntex S.A., Argentina); $48 \mathrm{~h}$ later they received $10 \mathrm{IU}$ of human chorionic gonadotropin (hCG, Profasi®, Laboratorios Serono, Méjico) and were paired with males of proven fertility. Females received $100 \mathrm{mg} / \mathrm{kg}$ or $200 \mathrm{mg} / \mathrm{kg}$ of ABZSO orally at the time of hCG administration, prior to mating. The control group received carboxymethylcellulose, vehicle used to prepare the drug suspension. Pregnant females were killed by cervical dislocation at day 4 of pregnancy and non fertilized oocyte and embryos were flushed from uteri. The possible effects of ABZSO were evaluated considering the fertilization rate, the total number of collected embryos per female; the percentage of embryos morphologically normal; the differentiation rate (determined by the relation between the number of blastocyst and the total of morphologically normal embryos) and the cleavage rate determined by counting the nuclei. The variables were analyzed on a per litter basis using the Kruskal-Wallis test. The fertilization rate was lower in females administered ABZSO at a dose of $200 \mathrm{mg} / \mathrm{kg}(\mathrm{P}<0.05)$. However, no statistically significant differences were found in the embryonic parameters after the administration of $100 \mathrm{mg} / \mathrm{kg}$ or 200 $\mathrm{mg} / \mathrm{kg}$ of ABZSO compared to the untreated control group $(\mathrm{P}>0.05)$. In conclusion, a single acute exposure to ABZSO prior to mating at around the time of fertilization at a dose higher than the one usually administered in human and veterinary medicine affects the fertilization rate but it has no adverse effects on early embryo development.

KEY WORDS: Albendazole Sulphoxide; Reproductive toxicity; Embryo development; Mouse.

\section{INTRODUCTION}

Maturation and oocyte fertility together with early embryo development are complex processes that can be affected by chemical agents generating detention of development or presence of anomalies. It has been demonstrated by using experimental models that reproductive toxic can affect the oocyte quality when used in hamsters (Perreaulta et al., 1992; Jeffay et al., 1996), mouse (Generoso et al., 1989; Mailhes \& Aardema, 1992; Scascitelly \& Pacchierotti, 2003) and rats (Berger \& Horner, 2003). One of the mechanisms of action of the reproductive toxic drugs is to perturb microtubule-dependent events occurring in the oocyte during meiotic maturation and fertilization and then during early steps of development. In mouse, nocodazole, a microtubule inhibitor, was administered to normally ovulated eggs at the time of sperm entry, when the egg is being activated to complete the second meiotic division. Remarkably high frequencies of embryonic lethality, expressed at around the time of implantation, were induced at this stage (Generoso et al.). One of the model toxics carbendazim, a microtubule poison, was used during oocyte maturation and fertilization in hamsters with results that show that a single exposure at critical times, coincident with microtubule-dependent meiotic events, can result in very early pregnancy loss (Perreaulta et al.; Jeffay et al.).

Among the anthelmintic agents, benzimidazole presents a broad spectrum of activity with high effectiveness and safety (Campbell, 1990), however administered during

\footnotetext{
* Area de Ciencias Morfológicas, Facultad de Ciencias Veterinarias, Universidad Nacional del Centro de la Provincia de Buenos Aires, Argentina. **Area de Reproducción. Facultad de Ciencias Veterinarias, Universidad Nacional del Centro de la Provincia de Buenos Aires, Argentina.
} 
gestation, it has demonstrated teratogenic effects such as external, skeletal and vascular abnormalities (Cristófol et al., 1997; Navarro et al., 1998, 1999; Teruel et al., 2003, 2009a; Capece et al., 2003; Moreti et al., 2005). Several studies suggest that the capacity of benzimidazolic drugs to bind with the tubulin of cells is responsible for the toxic effects observed during gestation (Delatour \& Parish, 1986; Piscopo \& Smoak, 1997) and its efficacy is attributed to its active albendazole sulphoxide metabolite (ABZSO), owing to its higher systemic availability compared to ABZ (Delatour et al., 1984).

While the effects of ABZSO at post implantation period of pregnancy are known, data on possible effects on earlier development are limited (Piscopo \& Smoak). On the other hand, data on its in vivo effects in relation to the fertilization process and early development stages are not available. For this reason, the pre-implantational mouse embryo is proposed as an experimental model to obtain information about the potential ABZSO effect when administered at the time of the hCG administration, prior to mating, on the fertilization rate and the preimplantational development of mouse embryos.

\section{MATERIAL AND METHOD}

Balb $\mathrm{C}$ female mice 5-8 weeks of age were mated with 12-14 weeks old Balb C males. Animals were kept on a dark/light regimen of 14 hours light alternating with 10 hours darkness, allotted in plastic boxes with free access to tap water and used according to the Animal Welfare Act (Facultad de Ciencias Veterinarias, Universidad Nacional del Centro de la Provincia de Buenos Aires).

Twenty four female were superovulated by intraperitoneal injection of 7.5 IU of equine chorionic gonadotropin (eCG, Novormon®, Laboratorios Syntex S.A. Argentina); followed $48 \mathrm{~h}$ later by intraperitoneal injection of $10 \mathrm{IU}$ of human chorionic gonadotropin (hCG, Profasi ${ }^{\circledR}$, Laboratorios Serono, México). Females were paired (1:1) with males at the time of hCG injection and checked for the presence of vaginal plugs $18-20 \mathrm{~h}$ post hCG (day one of pregnancy).

To analyze the effect of ABZSO, sixteen females were randomly assigned to two groups of eight animals each. Dosing suspension of ABZSO (racemic mixture, batch number 6-0011, Microsules Argentina S.A.) was prepared in carboxymethylcellulose (5\%) and administered orally by gavages at a dose of $100 \mathrm{mg} / \mathrm{kg}$ body weight (G100 Group) or $200 \mathrm{mg} / \mathrm{kg}$ body weight (G200 Group) at the time of hCG administration previous to mating. The control group (n: 8) was administered the same volume of carboxymethylcellulose.

Pregnant females were killed by cervical dislocation at day 4 of pregnancy ( $94 \mathrm{~h}$ post hCG). Unfertilized oocytes and preimplantation embryos were flushed from uteri using Ham F10 media (Gibco BRL, Life Technologies NY, USA) supplemented with $0.4 \%$ of bovine serum albumin (BSA Sigma Chemical Company, St. Louis, MO, USA) using a $30-\mathrm{g}$ needle on a 1-cc syringe.

The possible effects of ABZSO were evaluated considering the fertilization rate calculated by dividing the number of embryos by the number of embryos plus unfertilized oocytes, the total number of collected embryos per female; the percentage of embryos morphologically normal determined by the relation between the number of normal embryos and the total collected embryos percent (embryos morphologically normal were considered those with intact pellucida zone and with no asymmetry, blastomeres separated from the inner cell mass, with cytoplasm granulations or irregular shapes); the differentiation rate determined by the relation between the number of blastocyst and the total of morphologically normal embryos collected per cent; and the cleavage rate determined by counting the nuclei according to the air-drying technique of Tarkowski (1966). Briefly, the embryos were filled with drops of $1 \%$ sodium citrate for $8-10$ min at $37^{\circ} \mathrm{C}$, transferred to cleaned slides and fixed for $30 \mathrm{~s}$ by dropping methanol: acetic acid (3:1 v/v) over the embryos. The cells were stained with Giemsa solution (2\%) for $10 \mathrm{~min}$. The nuclei were examined under light microscopy. Additionally, the blastocysts were classified according to blastocoels development, as early blastocysts, medium blastocysts, and expanded blastocysts.

The variables were analyzed on a per litter basis using the Kruskal-Wallis test. The significance level was established at $\mathrm{P}<0.05$.

\section{RESULTS}

The fertilization rate was lower in females administered ABZSO at a dose of $200 \mathrm{mg} / \mathrm{kg}(\mathrm{P}<0.05$; Table I).

No statistically significant differences were found in the number of embryos collected by female after the administration of $100 \mathrm{mg} / \mathrm{kg}$ or $200 \mathrm{mg} / \mathrm{kg}$ of ABZSO compared to the untreated control group ( $\mathrm{P}>0.05$; Table I). Experimental and control embryos showed normal morphological characteristics no matter stadium of development (morulae or blastocyst) (P>0.05; Table I). 
TERUEL, M.; CATALANO, R. \& SALOMÓN, L. Albendazole sulphoxide administered prior to mating and its relation with fertilization and mouse embryo development. Int. J. Morphol., 29(3):816-820, 2011.

The cleavage rate expressed as number of cells per embryo was not affected by ABZSO administration $(\mathrm{P}>0.05$; Table II). No differences were observed when that parameter was analyzed in relation to the development stage (morulae or blastocysts) ( $\mathrm{P}>0.05$; Table II).
The differentiation rate was not affected by ABZSO administered at doses of $100 \mathrm{mg} / \mathrm{kg}$ or $200 \mathrm{mg} / \mathrm{kg}$ previous to mating ( $\mathrm{P}>0.05$; Table III). According to blastocoels development, the proportion of early blastocysts, medium blastocysts and expanded blastocysts did not show differences between groups ( $\mathrm{P}>0.05$; Table III).

Table I. Effect of albendazole sulphoxide (ABZSO) administered to Balb C mice prior to mating on fertilization rate and preimplantational embryo development.

\begin{tabular}{lccc}
\hline & Control group & G100 group & G200 group \\
\hline Fertilization rate $(\%)$ & $69.8 \pm 30.5 \mathrm{a}$ & $68.7 \pm 35.9 \mathrm{a}$ & $37.9 \pm 40.1 \mathrm{~b}$ \\
Number of embryos per female & $20.2 \pm 8.9$ & $24.0 \pm 8.5$ & $26.9 \pm 16.0$ \\
Normal morphological embryos $(\%)$ & $90.5 \pm 12.0$ & $98.8 \pm 2.2$ & $98.6 \pm 2.0$ \\
\hline
\end{tabular}

G100 and G200 groups: ABZSO administered at a dose of $100 \mathrm{mg} / \mathrm{kg}$ or $200 \mathrm{mg} / \mathrm{kg}$, respectively. Different letters within a file indicate statistical differences at $\mathrm{P}<0.05$. Values are presented as mean $\pm \mathrm{SD}$.

Table II. Cleavage rate expressed as number of cells in Balb C mice embryos from mothers treated with albendazole sulphoxide (ABZSO) prior to mating.

\begin{tabular}{lccc}
\hline & Control group & G100 group & G200 group \\
\hline In total embryos & $38.4 \pm 11.1$ & $35.4 \pm 4.1$ & $36.0 \pm 10.3$ \\
In morulae & $25.4 \pm 2.9$ & $27.2 \pm 6.4$ & $25.4 \pm 5.7$ \\
In blastocysts & $43.5 \pm 6.5$ & $40.6 \pm 2.8$ & $43.6 \pm 7.0$ \\
\hline G100 and G200 groups: ABZSO administered at a dose of $100 \mathrm{mg} / \mathrm{kg}$ or $200 \mathrm{mg} / \mathrm{kg}$, respectively. Values are presented as mean + SD
\end{tabular}

Table III. Blastocyst differentiation in Balb C mice treated with albendazole sulphoxide (ABZSO) prior to mating.

\begin{tabular}{lcccc}
\hline \multicolumn{1}{c}{ Group } & Differentiation rate & Early blastocysts (\%) & Medium blastocysts (\%) & Expanded blastocysts (\%) \\
\hline Control & $51,4 \pm 28,4$ & $39,0 \pm 16,2$ & $40,5 \pm 10,8$ & $43,7 \pm 21,6$ \\
G100 & $47,2 \pm 9,1$ & $44,3 \pm 26,8$ & $45,8 \pm 25,6$ & $19,2 \pm 7,4$ \\
G200 & $62,8 \pm 11,1$ & $33,8 \pm 20,3$ & $41,3 \pm 19,6$ & $30,5 \pm 21,7$ \\
\hline
\end{tabular}

G100 and G200 groups: ABZSO administered at a dose of $100 \mathrm{mg} / \mathrm{kg}$ or $200 \mathrm{mg} / \mathrm{kg}$, respectively. Values are presented as mean \pm SD.

\section{DISCUSSION}

Benzimidazoles are drugs broadly used in veterinary and human medicine. Numerous studies have been carried out with the aim of determining their potential toxicity during development. It has been shown that they cause alterations not only in early stages of gestation (Piscopo \& Smoak) but also during later stages, ranging from only a lowering in the litter weight to high percentages of reabsorptions, embryonary and fetal deaths or the presence of foetus with large anomalies at tissue or organic level (Mantovani et al., 1995; Capece et al.; Teruel et al., 2003; Moreti et al.).

When benzimidalole teratogenic effects are observed, they are closely related to the crossing of the placental barrier (Cristófol et al., 1995; Capece et al.). However, in the experimental model proposed, the possibility of observing any preimplantational development alteration is subjected to a previous drug action on the fertilization process.

In this study, we showed that ABZSO exposure (200 $\mathrm{mg} / \mathrm{kg}$ ) of female mouse at mating time led to a decrease of fertilization rate. However, the capacity of zygotes to divide and reach the blastocysts stage was not modified. Probably, the drug caused some change in the oocytes leading to a lower fertilization. On the other hand, the fact that no embryo toxic effects of benzimidazole drugs have been found in this study, agrees with the results obtained after administration of albendazole $(30 \mathrm{mg} / \mathrm{kg} \mathrm{bw} / \mathrm{d})$ to Charles River CD-1 mice for 10 days during pregnancy (Killeen \& Rapp, 1975), and the administration of ABZSO $(200 \mathrm{mg} / \mathrm{kg}$ ) to Balb C mice at day 2 of pregnancy (Teruel et al., 2009b). The preceding results support the hypothesis that regardless of the mouse strain, the embryo development 
would not be sensitive neither to ABZ nor to ABZSO.

The fact that both the number and morphology of collected embryos by female and their division capacity and differentiation to blastocysts did not differ among those collected from females form the control group and those from females receiving ABZSO prior to mating, suggests that although the lower percentage of fertilization obtained, the first segmentation divisions, the morulae formation and the differentiation to blastocysts, were not affected by the drug.

In conclusion, a single acute exposure to ABZSO prior to mating at around the time of fertilization at a dose higher than the one usually administered in human and veterinary medicine affects the fertilization rate but it has no adverse effects on early embryo development.

TERUEL, M.; CATAlanO, R. \& SALOMÓN, L. Albendazol sulfóxido administrado previo al apareamiento y su relación con la fertilización y el desarrollo embrionario de ratón. Int. J. Morphol., 29(3):816-820, 2011.

RESUMEN: El objetivo de este trabajo fue evaluar el efecto de albendazol sulfóxido (ABZSO) administrado a ratonas Balb C previo al apareamiento, sobre la tasa de fertilización y el desarrollo embrionario preimplantacional. Se utilizaron 24 hembras de 5 a 8 semanas de edad las que fueron inducidas a superovular por inyección intraperitoneal de 7,5 UI de gonadotrofina coriónica equina (eCG, Novormon ${ }^{\circledR}$, Laboratorios Syntex S.A. Argentina) seguidas, 48 h más tarde por 10 UI de gonadotrofina coriónica humana (hCG, Profasi ${ }^{\circledR}$, Laboratorios Serono, México). Al momento de recibir la dosis de hCG, fueron apareadas con machos de fertilidad probada. Las hembras fueron dosificadas oralmente con ABZSO disuelto en carboximetilcelulosa en dosis de $100 \mathrm{mg} / \mathrm{kg}$ (Grupo 100) y 200 mg/kg (Grupo 200) previo al apareamiento. El grupo control recibió carboximetilcelulosa. Las hembras preñadas fueron sacrificadas por dislocación cervical en el día 4 de preñez y se recolectaron ovocitos sin fertilizar y embriones preimplantacionales mediante el lavado de cuernos uterinos. Se determinó la tasa de fertilización, el número promedio de embriones recolectados por hembra, el porcentaje de embriones morfológicamente normales, el porcentaje de diferenciación y la velocidad de clivaje estimada por recuento de núcleos. Las variables fueron analizadas sobre la base de la camada utilizando el test de Kruskal-Wallis. La tasa de fertilización resultó menor para hembras que recibieron albendazol sulfóxido a razón de $200 \mathrm{mg} / \mathrm{kg}$ de peso $(\mathrm{P}<0,05)$; no obstante, no se observaron diferencias significativas en los parámetros embrionarios luego de la administración de $100 \mathrm{mg} / \mathrm{kg}$ ó $200 \mathrm{mg} / \mathrm{kg}$ de ABZSO comparado con el grupo control (P>0,05). En conclusión, la exposición aguda de ABZSO realizada previo al apareamiento a una dosis mayor de aquella utilizada en medicina humana y veterinaria afecta la tasa de fertilización pero no muestra efectos adversos sobre el desarrollo embrionario temprano.

PALABRAS CLAVE: Albendazol Sulfóxido; Toxicidad Reproductiva; Desarrollo embrionario; Ratón.

\section{REFERENCES}

Berger, T. \& Horner, C. M. In vivo exposure of female rats to toxicants may affect oocyte quality. Reprod. Toxicol., 17(3):273-81, 2003.

Campbell, W. C. Benzimidazole: Veterinary uses. Parasitol. Today, 6(4):130-3, 1990.

Capece, B.; Navarro, M.; Arcalis, T.; Castells, G.; Toribio, L.; Perez, F.; Carretero, A.; Ruberte, J.; Arboix, M. \& Cristòfol, C. Albendazole sulphoxide enantiomers in pregnant rats' embryo concentrations and developmental toxicity. Vet. J., 165(3):266-75, 2003.

Cristòfol, C.; Carretero, A.; Fernandez, M.; Navarro, M.; Sautet, J.; Ruberte, J. \& Arboix, M. Transplacental transport of netobimin metabolites in ewes. Eur. J. Drug Metab. Pharmacokinet., 20(3):167-71, 1995.

Cristòfol, C.; Navarro, M.; Franquelo, C.; Valladares, J. E.; Carretero, A.; Ruberte, J. \& Arboix, M. Disposition of netobimin, albendazole and its metabolites in the pregnant rat: Developmental Toxicity. Toxicol. Appl. Pharmacol., 144(1):56-61, 1997.

Delatour, P.; Garnier, F.; Benoit, E. \& Longin, C. A correlation of toxicity of albendazole and oxfendazole with their free metabolites and bound residues. J. Vet. Pharmacol. Ther., 7(2):139-45, 1984.

Delatour, P. \& Parish, R. Benzimidazole anthelmintics and related compounds: Toxicity and evaluation of residues. In: Rico, A. G. (Ed.). Drug Residues in Animals. New York, Academic Press, 1986. pp.175-203.

Jeffay, S. C.; Libbus, B. L.; Barbee, R. R. \& Perreault, S. D. Acute exposure of female hamsters to carbendazim (MBC) during meiosis results in aneuploid oocytes with subsequent arrest of embryonic cleavage and implantation. Reprod. Toxicol., 10(3):183-9, 1996. 
Generoso, W. M.; Katoh, M.; Cain, K. T.; Hughes, L. A.; Foxworth, L. B.; Mitchell, T. J. \& Bishop, J. B. Chromosome malsegregation and embryonic lethality induced by treatment of normally ovulated mouse oocytes with nocodazole. Mutat. Res., 210(2):313-22, 1989.

Killeen, J. \& Rapp, W. A segment II mouse teratology study of $S K \&$ F 62979. Unpublished project No. 74-1096 from Biodynamics Incorporated. Submitted to WHO by Smith, Kline and French. Joint FAO/WHO Expert Committee on Food Additives, 1975.

Mailhes, J. \& Aardema, M. Benomyl-induced aneuploidy in mouse oocytes. Mutagenesis, 7(4):303-9, 1992.

Mantovani, A.; Macri, C.; Ricciardi, C. \& Stazi, A. Histological alterations in gestational day 13 rat embryos from albendazole-treated dams. Cong. Anom., 35:455$66,1995$.

Moreti, D. L. C.; Lopes, R. A.; Vinha, D.; Sala, M. A.; Semprini, M. \& Friedrichi, C. Efectos del albendazol en el hígado de feto de rata. Estudio morfológico y morfométrico. Int. J. Morphol., 23(2):111-20, 2005.

Navarro, M.; Cristofol, C.; Carretero, M.; Arboix, M. \& Ruberte, J. Anthelmintic induced congenital malformations in sheep embryos using Netobimin. Vet. Rec., 142(4):86-90, 1998.

Navarro, M.; Canut, L.; Carretero, A.; Cristófol, C.; PérezAparicio, F.; Arboix, M. \& Ruberte, J. Developmental toxicity in rat fetuses exposed to benzimidazole netobimin. Reprod. Toxicol., 13(4):295-302, 1999.

Perreaulta, S. D.; Jeffay, S.; Poss, P. \& Laskey, J. W. Use of the fungicide carbendazim as a model compound to determine the impact of acute chemical exposure during oocyte maturation and fertilization on pregnancy outcome in the hamster. Toxicol. Applied. Pharmacol., 114(2):225-31, 1992.

Piscopo, S. E. \& Smoak, I. W. Comparison of effects of albendazole sulfoxide on in vitro produced bovine embryos and rat embryos. Am. J. Vet. Res., 58(9):103842, 1997.

Scascitelli, M. \& Pacchierotti, F. Effects of lindane on oocyte maturation and preimplantation embryonic development in the mouse. Reprod. Toxicol., 17(3):299-303, 2003.

Tarkowski A. K. An air-drying method for chromosome preparations from mouse eggs. Cytogenetics, 5:394-400, 1966.

Teruel, M. T.; Felipe, A. E.; Solana, H. D.; Sallovitz, J. M. \& Lanusse, C. E. Placental and fetal toxicity of albendazole sulphoxide in Wistar rats. Vet. Hum. Toxicol., 45(3):131-6, 2003.

Teruel, M.; García, V. \& Catalano, R. Effects of albendazole sulphoxide on embryonic, foetal and placental parameters in Wistar Rats. Int. J. Morphol., 27(4):114753, 2009a.

Teruel, M.; Catalano, R. \& Salomón, L. Efecto de albendazol sulfóxido sobre el desarrollo preimplantacional de embriones de ratón. Primer Encuentro Internacional Virtual de Educación e Investigación en Ciencias Morfológicas, 2009b. Disponible en: http:// www.primerencuentrovirtual.fcm.unc.edu.ar/.

Correspondence to:

Teruel, M.

Facultad de Ciencias Veterinarias

Universidad Nacional del Centro de la Provincia de Buenos

Aires

B7000GHG

Tandil

ARGENTINA

Email: mteruel@vet.unicen.edu.ar

Received: 05-01-2011

Accepted: 07-06-2011 